\title{
Eliminating Excessive Tariffs on Exports of Least Developed Countries
}

\author{
Bernard Hoekman, Francis $\mathrm{Ng}$, and Marcelo Olarreaga
}

\begin{abstract}
Although average OECD tariffs on imports from the least developed countries are very low; tariffs above 15 percent (peaks) have a disproportional effect on their exports. Products subject to tariff peaks tend to be heavily concentrated in agriculture and food products and labor-intensive sectors, such as apparel and footwear. Although the least developed countries benefit from preferential access, preferences tend to be smallest for tariff peak products. A major exception is the European Union, so that the recent European initiative to grant full duty-free and quota-free access for the least developed countries (the so-called Everything But Arms initiative) will result in only a small increase in their exports of tariff peak items (less than 1 percent of total exports). However, as preferences are less significant in other major OECD countries, a more general emulation of the European Union initiative would increase the least developed countries' total exports of peak products by US $\$ 2.5$ billion (11 percent of total exports). Although almost half of this increase is at the expense of other developing country exports, this represents less than 0.05 percent of their total exports. This trade diversion can be avoided by reducing tariff peaks to a uniform 5 percent applied on a nondiscriminatory basis. However, such a reform would imply no gains for the least developed countries, suggesting that the globally welfare-superior policy of nondiscriminatory elimination of tariff peaks should be complemented by greater direct assistance to poor countries.
\end{abstract}

Despite generally low average tariffs, the structure of protection in the Quad (Canada, the European Union, Japan, and the United States) is characterized by many tariffs above 15 percent. Such tariff peaks are often concentrated in products that developing countries export. They include major agricultural staple food products such as sugar, cereals, and fish; tobacco; certain alcoholic beverages, fruits, and vegetables; food industry products with a high sugar content; clothing; and footwear.

The existence of these peaks is a reflection of the political economy of trade policy. Powerful groups in the Organisation for Economic Co-operation and

Francis Ng is with the Development Research Group at the World Bank; Bernard Hoekman and Marcelo Olarreaga are with the Development Research Group at the World Bank and the Center for Economic Policy Research, London. Their e-mail addresses are bhoekman@worldbank.org, molarreaga@worldbank. org, and fng@worldbank.org, respectively. The authors are grateful to Ataman Aksoy, Elena Ianchovichina, Will Martin, Aaditya Mattoo, three anonymous referees, and participants in a seminar at the World Bank for helpful comments and suggestions. The authors also thank Gerard Durand, Alice Enders, Daniel Morales, and Javier Suarez for valuable advice and data and Lili Tabada for excellent assistance.

(C) 2002 The International Bank for Reconstruction and Development / THE WORLD BANK 
Development (OECD) countries have been able to keep barriers high partly because of the strategy followed by many developing countries of not participating in the reciprocal exchange of liberalization commitments under the General Agreement on Tariffs and Trade (GATT). The last set of GATT negotiations, the Uruguay Round, actually led to an increase in peaks, as tariffication of nontariff barriers in agriculture led to the imposition of very high duties on products that had previously been constrained by quotas. As a result, tariffs that are more than three times higher than the average tariff are not uncommon in OECD countries.

To some extent, the negative impact of excessive tariffs is offset by preferential access schemes such as the Generalized System of Preferences (GSP) and related programs. These should, in principle, help developing country exporters overcome the high tariff hurdles. In practice, preferences tend to be limited. The programs often exclude "sensitive" products or subject them to some type of quantitative limitation, either in terms of the amount that can be imported under the preferential rates (a tariff rate quota) or in terms of the countries that are eligible (Michalopoulos 1999, Hallaert 2000).

This article assesses the potential effects on least developed country (LDC) exports of duty-free access to the Quad markets on tariff peak items. ${ }^{1}$ The article is motivated by the European Union's Everything But Arms initiative, which offers duty-free and quota-free access to the European Union for all LDC exports except arms. ${ }^{2}$ We also assess the impact of extending duty-free access for tariff peak items to non-LDC developing country exporters and compare this to a reduction in peaks to a uniform 5 percent tariff that applies on a nondiscriminatory basis.

The article focuses on tariff peaks only—tariffs above 15 percent-for a number of reasons. First, peaks affect commodities that are of relatively greater importance to LDCs-that is, they account for a larger share of total LDC exports. Second, from a political economy point of view, these products face the highest protection in the Quad. Third, moving beyond tariff peaks to consider elimination of all tariffs on all imports from LDCs requires the use of a computable general equilibrium model of the world economy. Although such tools are readily available, they do not allow a detailed and disaggregated analysis of the effect of liberalization at the product and country level. Because we are interested in determining the likely impact of duty-free access on the pattern and composition of trade, we use a partial equilibrium approach. By limiting our focus to tariff peaks-which account for only a small share of the total

1. We use the U.N. definition of LDCs comprising 49 countries. See Hoekman, Ng, and Olarreaga (2001) for a list of these countries. The 49th member of this group, Senegal, is not included in the calculations that follow as it became an LDC after this article was completed.

2. The initiative entered into force in 2001, with the exception of exports of bananas (excluded until 2006) and sugar and rice (excluded until 2009). For a comprehensive description of the Everything But Arms proposal, see UNCTAD (2001). 
trade of most countries-such an approach is unlikely to lead to misleading conclusions. ${ }^{3}$ The exaggeration of resource shifts associated with a partial equilibrium approach is also likely to be mitigated by restricting attention to tariff peaks only. Finally, the partial equilibrium approach has an important advantage in that the effects of peaks are not diluted through aggregation into a small number of sectors, as is required if a general equilibrium simulation approach is used.

We do not quantify the effect of remaining nontariff barriers-the focus is solely on tariff peaks and preferences. Nontariff barriers are relatively unimportant in the Quad-only 1.2 percent of tariff lines are subject to such barriers in Canada, 4.2 percent in Europe, 2.6 percent in Japan, and 2.9 percent in the United States (see OECD 1997). However, nontariff barriers apply to a sector that is of great interest to developing countries-clothing, which is still constrained by quotas. By ignoring quotas and the associated rents, our analysis underestimates the potential export response by LDCs following duty-free and quota-free access for tariff peak products. However, given that the quotas restrict the most efficient developing country exporters and that all remaining quotas must be eliminated by the end of 2004 under the World Trade Organization (wTO) Agreement on Textiles and Clothing, any effect of preferential elimination of prevailing quotas for LDC exporters will be of short duration.

In the case of agriculture, the Uruguay Round led to tariffication of all nontariff barriers (with the exception of rice in Japan). ${ }^{4}$ Tariff rate quotas are often used. These involve two-tier tariff systems: A limited quantity enters subject to a low tariff, and all imports that exceed this tariff quota are subject to higher tariffs. In this article, we use out-of-quota tariffs as the appropriate measure of protection. This may lead to an overestimation of the effects of duty-free access. Note that the net effect of ignoring textile quotas and using out-of-quota tariffs for agricultural products is unclear, but that the two potential sources of bias are offsetting. In general, the approach used is conservative in that we assume only limited supply responsiveness to the changed incentives in LDCs.

Section I describes the extent and importance of existing tariff peaks in the Quad. The article discusses the preferential treatment granted to developing countries for these tariff peak products (section II) and the prevailing pattern of developing country exports (section III). ${ }^{5}$ Section IV presents a simple partial equilibrium model. Section $\mathrm{V}$ uses this model to estimate the impact of duty-free

3. See Ianchovichina, Mattoo, and Olarreaga (2001) and UnCTAD (2001) for general-equilibriumbased estimates of the gains for developing countries of unrestricted market access for all goods in the Quad. Although the methodology, product, and country coverage in these two studies differ from the present article, they all provide similar estimates of the increase in LDC export revenue and the export displacement for other developing countries.

4. Specific tariffs-frequently used for agricultural products in the Quad-have been converted into ad valorem equivalents using OECD $(1997,2000)$.

5. Under preferential treatment, we include both unilateral schemes, such as GSP, and those granted under bilateral free trade agreements. 
access for LDCs to the Quad and compares this with a nondiscriminatory reduction of peaks to 5 percent. Section VI concludes the article.

\section{Tariff Peaks and Imports in the Quad}

Between 6 and 14 percent of Quad tariff categories at the six-digit level of aggregation of the Harmonized System classification are above 15 percent (table 1). The United States, the European Union, and Japan have 200 to 300 such lines, whereas Canada has more than 700 tariff peaks. The average unweighted tariff in the Quad over all tariff peak products is 28 percent, more than four times the unweighted total average tariff of 6.2 percent. In the United States and Canada, most tariff peaks affect industrial products (more than 85 percent); in the European Union and Japan, most peaks affect agricultural products (91 and 77 percent, respectively). The maximum tariff rate at this level of aggregation is 340 percent for butter in Canada, 250 percent for edible bovine offal in the European Union, 170 percent for raw cane sugar in Japan, and 120 percent for ground nuts in shell in the United States.

In 1999, imports of products subject to tariff peaks in at least one member were US\$92.8 billion. More than 60 percent of these imports originated in developing countries (US\$55.2 billion) and potentially faced an average tariff of 28 percent. $^{6}$ This represented around 5 percent of total developing country exports to these high-income country markets. LDCs are more specialized in products subject to peaks, which affect 11 percent of their total exports to the Quad.

\section{Tariff Peaks and Developing Country Preferences}

Most developing countries enjoy preferential access to Quad markets, either through unilateral schemes such as the GSP, or through free trade agreements. In the case of Canada, Japan and the European Union, some 170 developing countries benefit from GSP (or better) preferences. ${ }^{7}$ In the case of the United States, 140 developing countries benefit from some type of preferential access. As shown in table 2, preferences are of a cascading nature; countries with free trade agreements generally get the best treatment, followed by LDCs and other developing countries. The United States grants preferences to the Andean Pact, the Caribbean, and Mexico (under the North American Free Trade Agreement). ${ }^{8}$ The European Union provides preferences for a large group of African, Caribbean,

6. Tariff preferences granted to developing countries through bilateral or unilateral schemes will bring down the tariff faced by these exporters.

7. The European Union was the first customs territory to grant GSP preferences to developing countries in 1971. See Kennan and Stevens (1997) or Hallaert (2000) for a detailed description of the European GSP.

8. In the simulations discussed in the following material, we also include preferences for developed countries that benefit from preferences in other Quad markets (see the notes in table 2). 


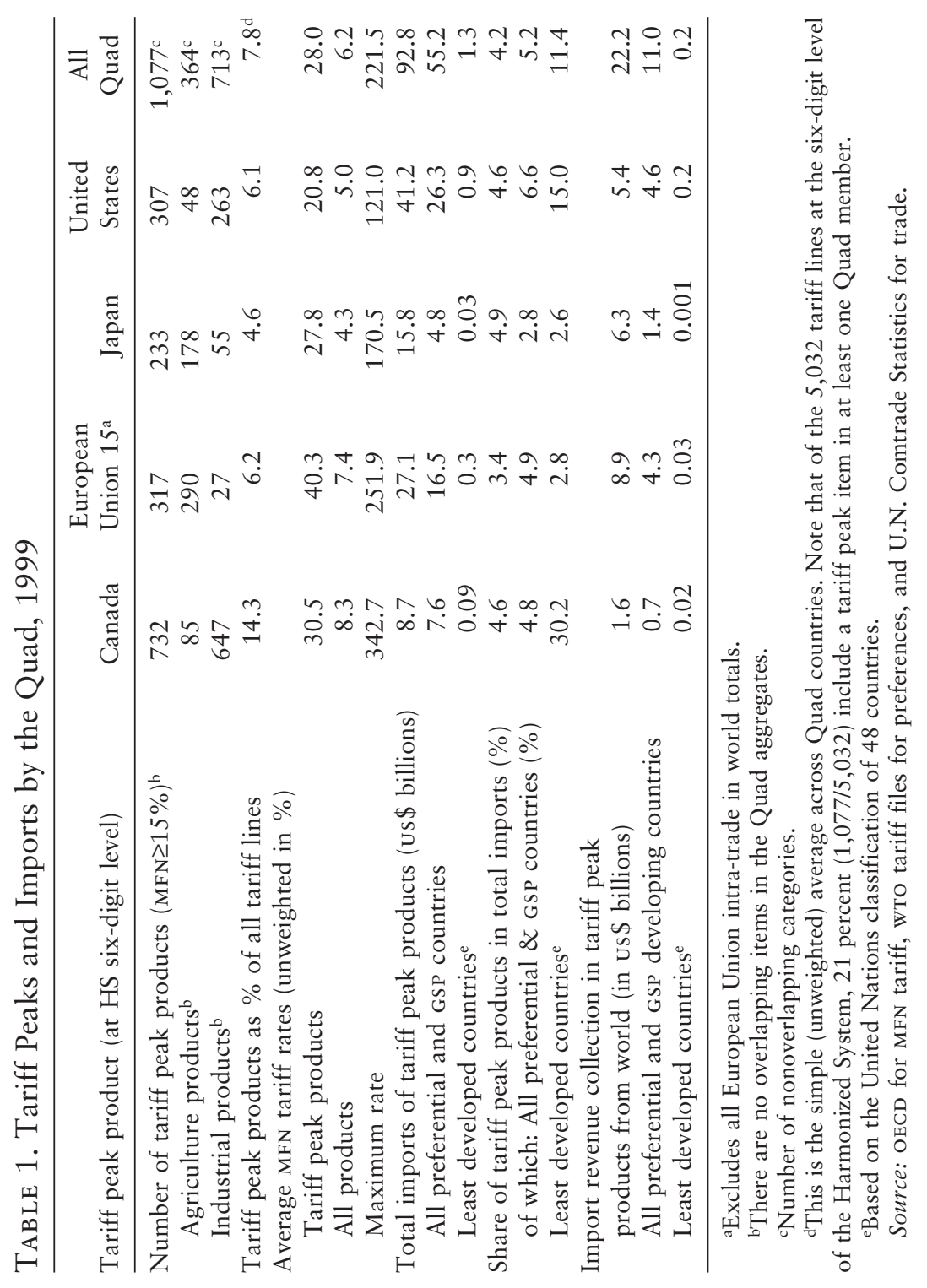


Table 2. Tariff Peaks and Preferential Duty Rates in the Quad, 1999

\begin{tabular}{|c|c|c|c|}
\hline \multirow[b]{2}{*}{ Preferential trade agreements/GSP } & \multirow[b]{2}{*}{$\begin{array}{l}\text { Number } \\
\text { of countries }\end{array}$} & \multicolumn{2}{|c|}{$\begin{array}{l}\text { Average preference rate } \\
\text { (unweighted percent) }\end{array}$} \\
\hline & & $\begin{array}{c}\text { Tariff } \\
\text { peak products }\end{array}$ & All goods at Hs- 6 \\
\hline \multicolumn{4}{|l|}{ Canada } \\
\hline United States & 1 & 7.1 & 1.6 \\
\hline Australia & 1 & 28.2 & 7.8 \\
\hline New Zealand & 1 & 28.2 & 7.8 \\
\hline Mexico & 1 & 15.9 & 3.1 \\
\hline Chile & 1 & 12.2 & 2.4 \\
\hline Israel & 1 & 11.8 & 2.5 \\
\hline Caribbean countries $^{\mathrm{a}}$ & 18 & 23.3 & 4.3 \\
\hline GSP-only beneficiaries ${ }^{\mathrm{b}}$ & 108 & 28.2 & 6.2 \\
\hline Least developed countries ${ }^{c}$ & 47 & 22.8 & 4.4 \\
\hline Other countries (MFN rate) & & $(30.5)$ & $(8.3)$ \\
\hline European Union & 15 & & \\
\hline Eastern Europe and Middle East ${ }^{\mathrm{d}}$ & 30 & 20.1 & 1.8 \\
\hline GSP-only beneficiaries ${ }^{\mathrm{e}}$ & 42 & 19.8 & 3.6 \\
\hline Least developed ACP countries ${ }^{f}$ & 37 & 11.9 & 0.8 \\
\hline Other ACP countries & 32 & 12.4 & 0.9 \\
\hline Other least developed countries ${ }^{\mathrm{h}}$ & 11 & 12.6 & 0.9 \\
\hline Other countries (MFN rate $)^{\mathrm{i}}$ & & $(40.3)$ & $(7.4)$ \\
\hline \multicolumn{4}{|l|}{ Japan } \\
\hline GSP-only beneficiaries ${ }^{j}$ & 127 & 22.7 & 2.3 \\
\hline Least developed countries ${ }^{\mathrm{k}}$ & 42 & 19.0 & 1.7 \\
\hline Other countries (MFN rate) & & $(27.8)$ & $(4.3)$ \\
\hline \multicolumn{4}{|l|}{ United States } \\
\hline Canada & 1 & 0.6 & 0.1 \\
\hline Mexico & 1 & 1.6 & 0.3 \\
\hline Israel & 1 & 0.6 & 0.1 \\
\hline ANDEAN $^{1}$ & 4 & 14 & 1.7 \\
\hline Caribbean community $^{\mathrm{m}}$ & 22 & 13.5 & 1.6 \\
\hline GSP-only beneficiaries $^{\mathrm{n}}$ & 80 & 16 & 2.4 \\
\hline Least developed countries ${ }^{\circ}$ & 38 & 14.4 & 1.8 \\
\hline Other countries (MFN rate) & & $(20.8)$ & $(5.0)$ \\
\hline
\end{tabular}

ancludes 18 Caribbean countries or territories under Commonwealth Caribbean Countries Tariff.

bExcludes eight developing countries: Albania, Aruba, Bosnia and Herzegovina, Macedonia, Mongolia,

Oman, Saudi Arabia, and the former Yugoslavia.

cExcludes Myanmar.

Includes countries with reciprocal and nonreciprocal trade agreements with the European Union.

eMost developing countries in Latin America and Asia; excludes Hong Kong, Rep. of Korea, and

Singapore (non-GSP nations).

fIncludes $37 \mathrm{ACP}$ and least developed countries under the Lomé Convention.

gIncludes 32 ACP countries under the Lomé Convention but not under the group of least developed countries.

hIncludes 11 least developed countries but not under ACP countries.

includes all industrial countries, Hong Kong, Korea, Singapore, and 14 transition countries.

¡127 countries; excludes Albania, Bosnia, Estonia, Latvia, Lebanon, Lithuania, Macedonia, Moldova, Vietnam, and the former Yugoslavia.

kExcludes three least developed countries: Comoros, Djibouti, and Tuvalu. Three others (Rep. of Congo, Kiribati, and Zambia) are included in the GSP group.

Includes Bolivia, Colombia, Ecuador, and Peru under the Andean Trade Preference Act.

mBased on 20 Caribbean countries under the Caribbean Basin Economic Recovery Act and the Bahamas and Nicaragua.

${ }^{n}$ Includes 80 developing countries or territories under the GSP scheme but excludes 29 other developing economies.

${ }^{\circ}$ Based on the United Nations 48 least developed countries but excludes 10 countries.

Source: World Trade Organization files. 
and Pacific countries-mostly former colonies of European states-and free trade agreement preferences. In the case of the European Union, two different groups of LDCs are constructed for purposes of analysis: African, Caribbean, and Pacific countries and others. In the case of Canada, developing countries are grouped into those benefiting from LDC, GSP, or Caribbean preferences and Mexico and Chile, which benefit from free trade agreements. Finally, in the case of Japan, developing countries are split into GSP and LDC beneficiaries.

On average, the preferential schemes are quite generous. In the European Union, the average tariff faced by LDCs is less than 1 percent, compared with the 7.4 percent average most-favored-nation (MFN) tariff. GSP preferences in the European Union are less generous but still imply a margin of more than 50 percent. Japan and the United States grant a 50 percent preference margin under their GSP regime and an average 60 percent preference for LDCs. Canada gives a 25 percent preference to GSP countries and 45 percent to LDCs.

Preferences are much less generous for tariff peak products. Preference margins for GSP beneficiaries in Canada, Japan, and the United States on tariff peak items are only 8, 18, and 23 percent, respectively. For LDCs, the margins increase to 25 percent in Canada and 30 percent in the United States and Japan. The exception is the European Union, with a 50 percent margin for GSP beneficiaries and a 70 percent margin for LDCs in tariff peak items.

Thus, although existing preferential schemes grant significant preferences to developing countries, these are concentrated in products with low tariffs (between 0 and 15 percent) rather than on tariff peaks. In other words, preferential schemes offer little protection against tariff peaks in the Quad, except for the European Union. Hoekman, Ng, and Olarreaga (2001) and the U.N. Conference on Trade and Development (UNCTAD 2001) provide more detailed data on the average MFN import duties on tariff peak products and preference margins granted by the Quad to different groups of developing countries.

\section{TARIFF PEAKs AND LDC Exports}

Simulation of the possible effects of duty-free access to the Quad requires data on global LDC exports of products that are subject to tariff peaks in these markets, because duty-free access to the Quad can result in redirection of exports to these markets and an increase in world prices (see section IV). During 1996-99, total LDC exports averaged $\$ 22.7$ billion, of which $\$ 17$ billion went to the Quad. ${ }^{9}$ More than $\$ 5.5$ billion of LDC exports to the world-25 percent of their total exports-were potentially affected by tariff peaks in Canada. Most of these affected exports are in apparel and clothing. More than 99 percent of LDC exports of apparel to the world are affected by an average tariff peak of 22 percent in

9. The simulations reported below use export data for 1996-99 as the base period. For a description of the product breakdown of LDC exports, see appendix B in Hoekman, Ng, and Olarreaga (2001). Data are drawn from the U.N. Comtrade database. 
Canada. There is almost no preferential access for LDCs in these items (the preference margin is only 8 percent), implying that tariff peak elimination by Canada is likely to have a significant effect on LDC exports. Exports of other developing countries (non-LDCs) potentially affected by Canadian tariff peaks are also concentrated in apparel, with even smaller preference margins (around 3 percent). However, Mexico and Chile benefit from a 66 percent preference margin in these items under their respective free trade agreements with Canada, bringing the tariff they face to around 10 percent.

Similarly, more than $\$ 3$ billion of LDC exports to the world, or 14 percent of all exports, are potentially affected by tariff peaks in the United States. Most LDC exports subject to tariff peaks in the United States are concentrated in apparel (\$2.6 billion), facing an average tariff of 19 percent. Tobacco is another tariff peak item that is an important export item for developing countries. In the case of LDCs, more than 95 percent of their total exports of tobacco to the world potentially face a tariff peak in the United States of 63 percent (the MFN rate on these products averages 73 percent, but there is a 14 percent preference margin for LDCs).

The numbers are smaller in the case of Japan and the European Union, with tariff peaks in each market affecting some $\$ 500$ and $\$ 800$ million of LDC exports to the world, respectively. Although these numbers are small in absolute terms, the effect of peaks in these markets on specific LDCs may be quite large. For example, in the 1996-99 period, Djibouti, Kiribati, Somalia, and Tuvalu together exported less than $\$ 50$ million to the world.

LDC exports affected by European Union tariff peaks are concentrated in meat and fish products, crustaceans, sugar, tobacco, and footwear. With the exception of meat, fish, or mollusk products and sugar, all of these exports benefit from full duty-free access into the European Union. In the case of preparations of meat, the 68 percent preference margin brought the tariff faced by LDC exporters down to around 10 percent. In the case of sugar, however, the preference margin granted to LDCs is quite small; their exports faced an average tariff of 29 percent. $^{10}$

LDC exports to the world that are affected by Japanese tariff peaks include sugar, raw hides and skins, and footwear. Of these three products, the preference margin for sugar is only 5 percent, bringing the tariff faced by LDC exporters to 66 percent. By contrast, full preferences (duty-free access) are granted for raw hides and skins, whereas in the case of footwear an 80-percent preference margin applies to LDCs.

\section{A Simple Partial Equilibrium Model}

To estimate the impact that the elimination of tariff peaks may have on LDC exporters, we use a simple partial equilibrium model. World markets are assumed 
to be perfectly competitive and integrated in the sense that there is no further scope for arbitrage across countries. Products traded in world markets under the same six-digit Harmonized System classification are considered to be perfectly homogenous. Each six-digit Harmonized System product category represents only a small share of the economy, so that the effect on other product markets of changes in a particular category is negligible.

Import demand $M_{i}$ for each Harmonized System six-digit product of country $i=$ United States, European Union, Canada, Japan is given by:

$$
M_{i}=A_{i} /\left[P_{W}\left(1+T_{i}\right)\right]^{E},
$$

where $E$ is the import demand elasticity (common to all countries in our simulations), ${ }^{11} P_{W}$ is the world price; $T_{i}$ is the MFN tariff in country $i$; and $A_{i}$ is a demand parameter in country $i$. We assume throughout that tariffs are kept constant in the rest of the world. Rest-of-the-world import demand $M_{R O W}$ is therefore

$$
M_{\text {ROW }}=A_{\text {ROW }} /\left[P_{W}\right]^{E} \text {. }
$$

Export supply $X_{j \rightarrow i}$ from country $j$ to country $i$ is given by

$$
X_{j \rightarrow i}=B_{j}\left[P_{W}\left(1+T_{i} \Pi_{i \rightarrow j}\right)\right]^{\theta},
$$

where $\theta$ is the export supply elasticity (common to all countries), $B_{j}$ is a supply parameter, and $\Pi_{i \rightarrow j}$ is the level of tariff preference granted by country $i$ to exports from $j$. Thus, if $\Pi_{i \rightarrow j}=0$, imports of $i$ from $j$ have to pay country $i$ 's MFN tariff. Similarly if $\Pi_{i \rightarrow j}=2$, exports from $j$ receive the domestic price in $i$.

The equilibrium world price, $P \underset{W}{E}$, is obtained by solving for the world price in the world market-clearing condition, that is, the price for which

$$
\left[\sum_{k} M_{k}-\sum_{j} X_{j}=0\right] \Leftrightarrow P_{W}^{E}=\left[A_{i} /\left(1+T_{i}\right)^{\mathrm{E}}+A_{R O W}\right] /\left[\sum_{j} B_{j}\left(1+T_{i} \Pi_{i \rightarrow j}\right)^{\theta}\right] .
$$

All demand and supply parameters are calibrated using U.N. trade data (value and quantities) at the six-digit level of the Harmonized System classification, MFN tariffs and preference margins of country $i$ (see the appendix for data sources): ${ }^{12}$

$$
B_{j}=X_{j} /\left[1+T_{i} \Pi_{i \rightarrow j}\right]^{\theta} ; A_{\text {ROW }}=M_{\text {ROW }}\left[P_{W}\right]^{E} ; A_{i}=M_{i}\left[P_{W}\left(1+T_{i}\right)\right]^{E} .
$$

Using the calibrated parameters in expression (5) and replacing them in the righthand side of equation (4) allows us to simulate the effect on world prices (and developing countries' export revenue) of changes in country i's tariff peaks on either a preferential or an MFN basis. Once the new world price is obtained, we substitute it into equations (1) and (3). Using the new tariff or preference margin, we then obtain the new import demand and export supply quantities for each country.

11. The six-digit Harmonized System import demand elasticities are derived from Stern, Francis, and Schumacher (1976) and Shiells, Stern, and Deardorff (1986).

12. Given that goods are perfectly substitutable, exports of $j$ to the rest of the world need to receive the same price as exports to country $i$. 
To determine the effect of a reduction in tariff peaks on world prices, we differentiate equation (4) with respect to $t_{i}$. This yields

$$
\begin{aligned}
\frac{\partial p_{W}^{E}}{\partial t_{i}}= & \frac{1}{E+\theta}\left[\frac{A_{R O W}+A_{i} /\left(1+T_{i}\right)^{E}}{\sum_{j} B_{j}\left(1+T_{i} \Pi_{i \rightarrow j}\right)^{\theta}}\right]^{1 /(\theta+E)-1}\left(-E \frac{A_{i} /\left(1+T_{i}\right)^{E-1}}{\sum_{j} B_{j}\left(1+T_{i} \Pi_{i \rightarrow j}\right)^{\theta}}-\right. \\
& \left\{\sum_{j} B_{j} \theta\left(1+T_{i} \Pi_{i \rightarrow j}\right)^{\theta-1} \Pi_{i \rightarrow j}\right\} \frac{A_{R O W}+A_{i} /\left(1+T_{i}\right)^{E}}{\left.\mid \sum_{j} B_{j}\left(1+T_{i} \Pi_{i \rightarrow i}\right)^{\theta}\right]^{2}}<<
\end{aligned}
$$

Thus, a reduction of country i's tariff peaks will necessarily lead to an increase in world prices. This does not necessarily lead to an increase of country $j$ 's export revenue, because some countries benefit from preferential access so that their export price is partly determined by the tariff. The export revenue of country $j$ is given by

$$
E R_{j}=P_{W}\left(1+T_{i} \Pi_{i \rightarrow j}\right) X_{j}=B_{j}\left(P_{W}\left[1+T_{i} \Pi_{i \rightarrow j}\right]\right)^{\theta+1} .
$$

The change in export revenue following a change in country $i$ 's tariff is obtained by differentiating the right-hand side of equation (7) with respect to

(8) $\left[\left(\partial E R_{m}\right) /\left(\partial T_{i}\right)\right]=B_{j}(\theta+1)\left(P_{W}\left[1+T_{i} \Pi_{i \rightarrow j}\right]\right)^{\theta}\left(\left[\left(\partial P_{W}\right) /\left(\partial T_{i}\right)\right]+P_{W} \Pi_{i \rightarrow j}\right)$.

If country $j$ has no preferential access to country $i$ 's market (that is, $\Pi_{i \rightarrow j}=0$ ), a tariff cut will necessarily increase the export revenue of country $j .{ }^{13}$ Similarly, if country $j$ has full preferential access to country $i$ 's market (that is, $\Pi_{i \rightarrow j}=1$ ), a tariff cut will reduce the export revenue of country $i .{ }^{14}$ More generally, the export revenue of country $j$ will increase following a tariff reduction in country $i$ if

$$
\left|\left(\partial P_{W} / \partial T_{i}\right)\left(T_{i} / P_{W}\right)\right|=T_{i} \Pi_{i \rightarrow j} \cdot
$$

That is, the elasticity of the world price with respect to the tariff must be smaller than the tariff faced by exporter $j$ in country $i$. Thus, a crucial element for the analysis of the effects of tariff reductions in the Quad on the export revenue of developing countries is the degree of preferential access that developing countries initially enjoy in Quad markets.

Changes in export revenue are a function of current export levels. This implies that estimated export growth will be modest for countries that do not export much in the base period. This problem is attenuated by calibrating the model using global export supply and not bilateral export flows. However, calibration

13. To see this, note that the term in brackets on the right-hand side of equation (8) will have the same sign as the change in world prices (which is negative).

14. The term in brackets on the right-hand side of equation (8) will now necessarily be greater than zero because the elasticity of world price with respect to the tariff change in country $i$ is smaller than the initial tariff in absolute value (unless we are in the presence of the Metzler paradox, that is, when a reduction in the tariff increases domestic prices). 
ignores potential trade ("production") deflection that could generate large export growth in countries with important domestic production, but no exports in the base period. In principle, countries that are given large preferences have an incentive to redirect their whole domestic production to the export market. Not allowing for this is a shortcoming of the methodology that will tend to underestimate the potential for export growth. ${ }^{15}$

To determine the effect on world prices of an increase in preferential access for a subset of countries, it is necessary to also determine the impact on exporters in the rest of the world. The derivative of the world price, given in equilibrium by equation (4), with respect to the degree of preference $\left(\Pi_{i \rightarrow j}\right)$ is clearly negative, suggesting that any increase in the tariff preferences that country $i$ grants to country $j$ will reduce world prices. This in turn will reduce the export revenue of exporters in the rest of the world.

Finally, we can measure the change in welfare in the exporting country associated with a change in preferential access or tariffs in the importing country by looking at the exporters' producer surplus. The change in welfare is

$$
\Delta W_{j}=\int_{P_{j}^{X, 0}}^{P_{j}^{X}, 1} B_{j}\left[P_{j}^{X}\right]^{\theta} d P_{j}^{X}=\left[\left(B_{i}\right) /(\theta+1)\right]\left[\left(P_{j}^{X, 0}\right)^{\theta+1}-\left(P_{j}^{X, 0}\right)^{\theta+1}\right],
$$

where $\Delta W_{j}$ is the change in welfare in exporting country $j$ and $P_{j}^{X, T}$ is the export price faced by exporters in country $j$ at time $T$ (where $T=0$ for the pre-tariffchange period and $T=1$ after the tariff change in the importing country).

\section{Elimination of Tariff Peaks in the Quad}

This section estimates how LDC exports would change if Quad members were to grant duty-free access to all LDC exports of tariff peak items. It also calculates the impact of a nondiscriminatory (MFN) reduction in all tariff peaks to a level of 5 percent (the Quad average). Each case groups developing countries according to the type of preference that they receive, distinguishing between LDCs, GSP beneficiaries, and free trade agreement partners. ${ }^{16}$ In all simulations, we also take into account the existence of free trade agreements between industrial countries, although we do not report results for changes in exports of industrial countries. ${ }^{17}$ The numbers that are reported are aggregations of all affected 6-digit tariff peak items.

Table 3 summarizes the expected changes in export revenue and welfare for LDCs and other developing countries if LDC exporters were to obtain full duty-

15. In other words, the export supply elasticity may be much larger than the 0.5 assumed in the analysis. To partially correct for this, we also run some simulations with an elasticity of export supply equal to 2 for products in which the preference margin is larger than 30 percent.

16. Stevens and Kennan (2000) have identified more than 30 tariff regimes in the European Union. We follow them in working with only the major aggregate categories/groups.

17. These are available from the authors on request. 
TABle 3. Impact of Duty-Free Access to Quad Markets for Least Developed Country Exporters

(millions of dollars)

\begin{tabular}{lccccc}
\hline Indicator & Canada & $\begin{array}{c}\text { European } \\
\text { Union }\end{array}$ & Japan & United \\
States & Quad \\
\hline Change in LDC exports & 1,602 & 185 & 496 & 1,107 & 2,497 \\
& $(7.20)$ & $(0.83)$ & $(2.23)$ & $(4.97)$ & $(11.22)$ \\
Change in GSP beneficiary exports & -558 & -100 & -292 & -387 & -929 \\
& $(-0.03)$ & $(-0.01)$ & $(-0.02)$ & $(-0.04)$ & $(-0.05)$ \\
Change in all developing & 1,013 & 72 & 204 & 654 & 1,362 \\
country exports & $(0.03)$ & $(0.00)$ & $(0.01)$ & $(0.02)$ & $(0.04)$ \\
Change in imports in the Quad & 15 & 2 & 3 & 108 & 117 \\
& $(0.01)$ & $(0.00)$ & $(0.00)$ & $(0.01)$ & $(0.01)$ \\
Change in LDC welfare & 1,159 & 122 & 332 & 915 & 1,694 \\
& $(0.67)$ & $(0.07)$ & $(0.19)$ & $(0.53)$ & $(0.99)$ \\
\hline
\end{tabular}

Note: Figures in parentheses are percentages of values in the base year (1996-98 averages).

Source: Authors' calculations.

free access for tariff peak items in each Quad market. The European Everything But Arms initiative would increase LDC tariff peak exports by only $\$ 185$ million (less than 1 percent of total LDC exports). This partly reflects the fact that LDCs already enjoy relatively good access to the European Union. If all the Quad members granted unrestricted access to LDC exports of tariff peak products, the increase in export revenue could be as large as $\$ 2.5$ billion (or 11 percent). ${ }^{18}$ Most of this would be due to better access to Canada and the United States. ${ }^{19}$

Exports from other developing countries would fall by as much as $\$ 1.1$ billion. ${ }^{20}$ This is equivalent to one-third of the total increase in LDC exports, but represents only 0.05 percent of total developing country exports. Thus, although trade diversion against other developing country sources would occur, the relatively small magnitude of LDC exports implies that in relative terms this would have negligible effects on the affected countries. Welfare changes for non-LDCs would be close to zero, whereas LDCs would see their welfare increase by 1 percent of GDP (table 3).

18. Note that the export changes across Quad markets cannot be simply added to obtain the total change due to all Quad members granting duty-free access to LDCs on tariff peak items. This is because in some cases tariff peaks on a six-digit item are found in more than one Quad market. It is therefore necessary to correct for double counting.

19. As a robustness check, we also performed some simulations for which the elasticity of export supply was increased to 2 whenever the preference margin was larger than 30 percent. This increased LDC exports by almost an extra \$1 billion. Most of this increase was generated in Japan, where preferences are large on products that LDCs export in small quantities but where there is potential for supply expansion.

20. This is made up of a loss of $\$ 929$ million incurred by GSP beneficiaries and a loss of $\$ 206$ million incurred by other developing countries that enjoy preferential access to the Quad. 
Total imports into the Quad associated with duty-free access for peak products would expand by only a modest $\$ 117$ million (0.01 percent). ${ }^{21}$ The reason for this very small increase is that imports from other sources (industrial and developing countries) would fall and tariff revenue would be transferred. This suggests there is not a compelling reason to be concerned with possible adjustment costs for domestic import-competing industries located in the Quad. However, it also implies that a MFN reduction in tariff peaks would result in a significant expansion of exports by OECD countries.

The distribution of changes in export revenue across products and countries would vary across Quad members (figure 1). In the case of the European Union, two-thirds of the $\$ 185$ million increase in LDC export revenue would be concentrated in sugar and confectionery. The main beneficiaries would be Malawi, Zambia, and Mozambique, with 27, 19, and 15 percent of the total increase in LDC sugar exports, respectively. (Note, however, that the Everything But Arms initiative delays liberalization of LDC exports of sugar until 2009.) Some 10 percent of the total increase in exports to the European Union would occur in meat products. Because these are subject to phytosanitary standards that may be difficult for LDCs to satisfy, the estimated export increase might be too optimistic. ${ }^{22}$ The main beneficiary in terms of the absolute increase in exports to the European Union would be Madagascar. Its exports would increase by $\$ 26$ million or about 4 percent of total exports in 1999 . In relative terms, the LDC that would gain the most from duty-free access for tariff peak items in the European Union would be the Maldives, with a 19 percent increase in exports ( $\$ 14$ million). ${ }^{23}$

In the case of Japan, most of the increase (90 percent) would be concentrated in sugar and confectionery. Malawi, Zambia, and Mozambique again are predicted to capture most of this increase. Bangladesh would benefit the most in absolute terms, with an export increase of $\$ 229$ million (47 percent of the total increase in LDC exports to Japan). This represents around 5 percent of Bangladesh exports in 1999. In relative terms, the main beneficiaries would be Somalia (a 43 percent increase in exports or $\$ 13$ million) and Cape Verde (a 23 percent increase in exports or $\$ 4.4$ million).

In the case of Canada and the United States, most of the expansion in exports would occur in apparel and clothing and footwear. The main beneficiary would be Bangladesh, with an increase of more than $\$ 1$ billion in exports, more than

21. The increase in total imports in each Quad member is measured as the difference between actual imports and estimated imports at the new domestic price; that is, it excludes the increase in LDC imports that is simply explained by tariff revenue transfers.

22. The main beneficiary is predicted to be Sudan, which is unlikely to be able to export meat to the European Union due to the existence of foot and mouth disease. This is an example of the overestimation of changes in exports that can arise due to the assumption of product homogeneity across markets.

23. For more details in terms of the increase in exports by country associated with each Quad member granting duty-free access, see table 7 in Hoekman, Ng, and Olarreaga (2001). 

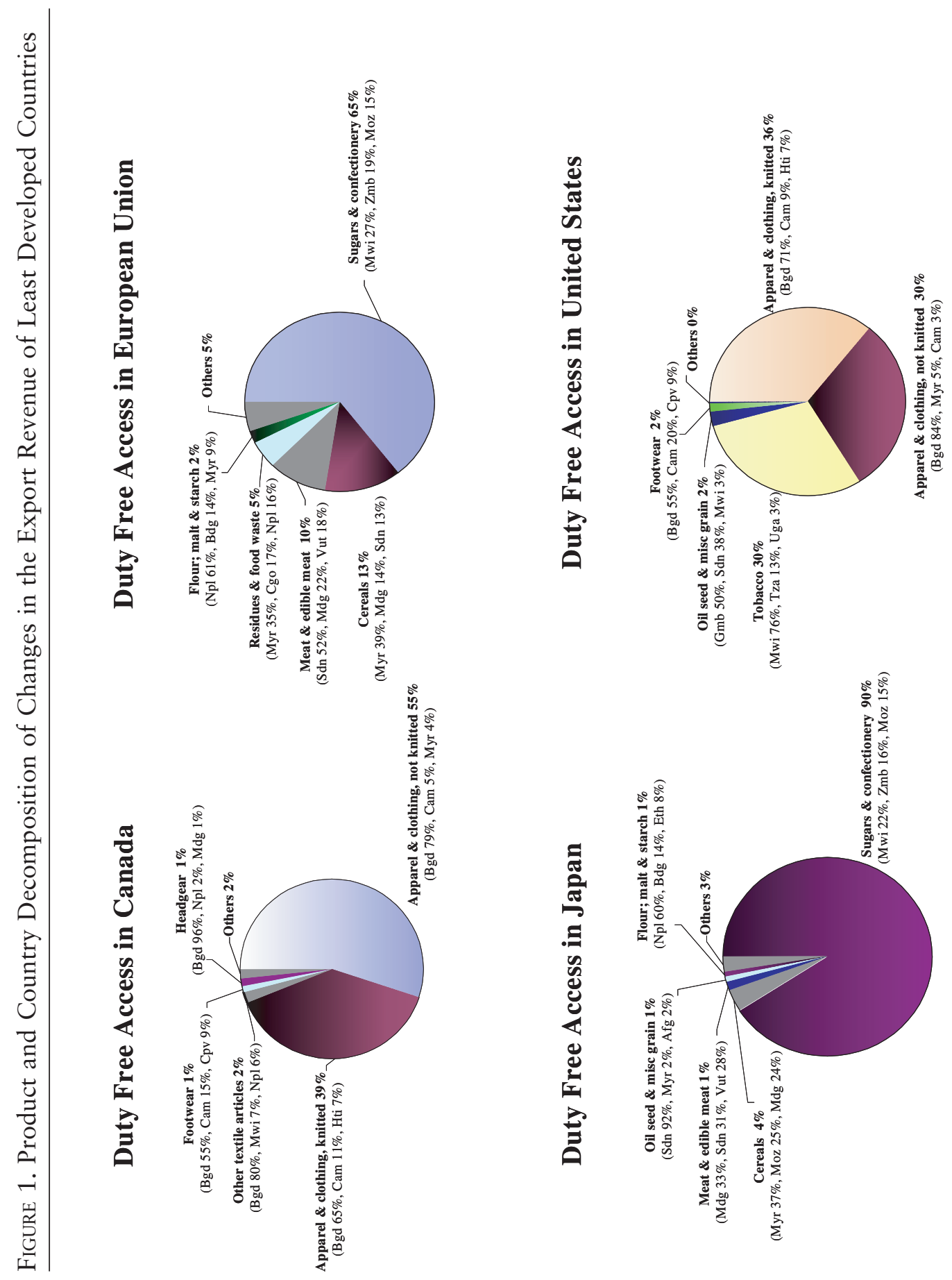
20 percent of its total exports in 1999. In relative terms, Liberia, Haiti, Laos, and Cambodia would gain substantially from the elimination of tariff peaks in Canada, with export increases of more than 20 percent. In the U.S. market, tobacco is also an important tariff peak item. Elimination of tariffs would benefit such producers as Malawi, which would be expected to experience a 25 percent increase in exports.

In the aggregate, the losses associated with the displacement of exports from other developing countries would be small and not concentrated. In principle, it would be expected that the major losers from preferential elimination of tariff peaks for LDCs would be developing countries that currently benefit from preferences. These include African, Caribbean, and Pacific countries that are not LDCs and countries with free trade agreement status, such as Mexico. The African, Caribbean, and Pacific countries that do not benefit from the Everything But Arms initiative would lose only $\$ 21$ million from its implementation. However, more than 90 percent of the contraction would occur in sugar exports. Because sugar is excluded from the initiative until 2009, the loss for the non-LDC African, Caribbean, and Pacific members would fall to just $\$ 1$ million. ${ }^{24}$ More than 60 percent of the potential loss for African, Caribbean, and Pacific countries would be concentrated in Mauritius, Fiji, Guyana, and Jamaica. None of these countries would lose more than 0.1 percent in terms of export revenue.

In the case of Canada and the United States, the effect on Mexico and the Caribbean would be negligible: a decline of $\$ 20$ million on a base of total exports of more than $\$ 150$ billion. Generally, there is not a single developing country for which the loss in export revenue would represent more than 0.7 percent of its total exports. If Canada granted duty-free access to LDCs for tariff peak products, Jamaica would incur the largest relative loss, a decline of 0.63 percent in its global exports.

\section{Nondiscriminatory Reduction of Tariff Peaks}

Preferential liberalization of trade is inferior to nondiscriminatory liberalization in welfare (efficiency) terms. The reason is that trade diversion can easily occur, whereby less efficient suppliers that are granted preferential access are able to force more efficient ones out of a market. Consumers then end up paying too much for the products concerned, with associated efficiency losses.

A reduction in all tariff peaks in the Quad to 5 percent, applied on a nondiscriminatory basis to all exporters, would eliminate all the gains incurred by LDCs under the preferential scenario (table 4). LDCs would not only need to compete with other developing and industrial countries in Quad markets but the value of their current preferential access under GSP or LDC preferential schemes would

24. Note that for the other two products for which implementation of duty-free access has been delayed, the loss in terms of export revenue for non-LDC African, Caribbean, and Pacific countries would be negligible: around $\$ 0.3$ million for bananas and $\$ 0.2$ million for rice. 
Table 4. Impact of Reducing Quad Tariff Peaks to 5 Percent on a Most-Favored-Nation Basis

(millions of dollars)

\begin{tabular}{lccccc}
\hline Indicator & Canada & $\begin{array}{c}\text { European } \\
\text { Union }\end{array}$ & Japan & $\begin{array}{c}\text { United } \\
\text { States }\end{array}$ & Quad \\
\hline Change in LDC exports & -116 & -47 & -94 & 128 & -71 \\
& $(-0.52)$ & $(-0.21)$ & $(-0.42)$ & $(0.57)$ & $(-0.32)$ \\
Change in GSP beneficiary exports & 1,512 & 797 & $-3,932$ & 2,949 & 423 \\
& $(0.09)$ & $(0.08)$ & $(-0.22)$ & $(0.33)$ & $(0.02)$ \\
Change in all developing & 1,294 & 645 & $-4,126$ & 2,659 & -110 \\
country exports & $(0.04)$ & $(0.02)$ & $(-0.14)$ & $(0.09)$ & $(0.00)$ \\
Change in imports in the Quad & 1,223 & 628 & 826 & 5,862 & 7,343 \\
& $(0.64)$ & $(0.08)$ & $(0.26)$ & $(0.66)$ & $(0.34)$ \\
Change in LDC welfare & -78 & -32 & -62 & 86 & -45 \\
& $(-0.05)$ & $(-0.02)$ & $(-0.04)$ & $(0.05)$ & $(-0.03)$ \\
\hline
\end{tabular}

Note: Figures in parentheses are percentages of values in the base year (1996-98 averages).

Source: Authors' calculations.

erode. ${ }^{25}$ The same would be true for non-LDC developing country exporters. As a result, under an MFN scenario, aggregate exports of developing countries as a group would actually fall slightly. Total imports by Quad members would expand by some $\$ 7.3$ billion, reflecting greater exports by OECD countries.

Two implications emerge from this analysis. First, the net gain to developing countries of a nondiscriminatory elimination of tariff peaks would be essentially zero. However, this would be due to an expected decline in exports to Japan; exports to the other Quad members would increase significantly, reflecting the importance of textiles and clothing for developing countries. However, LDCs would not see export expansion of tariff peak items in any Quad market. Second, a unilateral MFN elimination of all tariff peaks in the Quad could be difficult to realize in political terms because it would lead to a nonnegligible increase in import penetration in the Quad. Thus, an MFN reduction of tariff peak items would likely require a broader context that would allow for reciprocal concessions to be offered by countries that would see their exports expand. That is, MFN elimination would likely require a wTO round of trade negotiations.

\section{Caveats}

Although we have made a number of assumptions that limit the supply response to tariff peak elimination, the estimated gains from preferential access may nonetheless be too high. ${ }^{26}$ Though expanding exports to a particular market by redi-

25. The decline in Japan would be concentrated in leather footwear, where the MFN tariff is 23-30 percent and GSP preferences were around 60 percent in the late 1990s. If this preference margin were eliminated, OECD exporters would increase their market share significantly.

26. We could argue that the static nature of the simulations underestimates the potential export gains for LDCs. Once we allow for investment (foreign direct investment), the supply response in LDCs to large tariff preference margins in the Quad may be much higher than that assumed in the simulations. 
recting exports from other regions would not require an increase in total supply, it would require the establishment of strong business relationships and a good reputation as a supplier in the new market. This might limit the gains from these preferential initiatives.

The estimates might also be overly rosy in that they assume that access is truly free. In practice, any type of preference will be accompanied by rules of origin and may remain subject to the threat of contingent protection-antidumping, countervailing duties, and safeguard actions. These types of policy instruments can be used to make duty-free access irrelevant in practice. Examples abound of protectionist lobbying in Quad members to tighten GSP rules of origin to restrict the ability of beneficiaries to significantly expand exports (see Bovard 1991 for examples in the United States). Rules of origin are also costly to administerthe tariff equivalent of the associated red tape can be significant. Herin (1986) estimates that the ad valorem cost of fulfilling rules of origin in trade between the European Union and other European countries (that in principle benefited from free trade status) was high enough for some 25 percent of all trade to pay the MFN tariff rather than document origin. Similarly, Sapir (1997) shows that in 1994, only half of total European imports that could potentially benefit from the GSP entered under this preferential regime. The other half entered on an MFN basis, reflecting the combined effect of rules of origin and tariff quotas.

The wTо includes an Agreement on Rules of Origin that aims to foster the harmonization of the rules used by members. The agreement calls for a work program to be undertaken by a technical committee, in conjunction with the World Customs Organization, to develop a classification system regarding the changes in tariff subheadings based on the Harmonized System that constitute a substantial transformation (Hoekman and Kostecki 2001). ${ }^{27}$ The harmonization program provides a potential solution to problems of rules of origin. The rules of origin are intended to be applied for nonpreferential commercial policy instruments-tariffs, import licensing, antidumping, and so forth-but there is no reason why they could not be applied to preferential trade as well.

The threat of antidumping and similar instruments of contingent protection can also make duty-free access redundant if there is a probability that once exports have expanded they will be targeted by such mechanisms. It is therefore

27. Rules of origin are intended to prevent trade deflection and to determine where a good originates for duty purposes when two or more countries are involved in the production of a product. The general rule is that the origin of a product is the one in which the last substantial transformation took place, that is, the country in which significant manufacturing or processing occurred most recently. Significant or substantial is defined as sufficient to give the product its essential character. Various criteria can be used to determine whether a substantial transformation occurred. These include a change in tariff heading - as a result of whatever processing was performed, the good is classified in another category of the Harmonized System - the use of specific processing operations that do (or do not) imply substantial transformation, a test based on the value of additional materials embodied in the transformed product, or the amount of value added in the last country where the good was transformed. See Hoekman and Kostecki (2001). 
important that duty-free access schemes exempt LDCs from the application of antidumping and safeguard actions. Although this may be politically difficult to achieve, the small trade flows concerned should make such a promise relatively painless in practice.

Finally, it should be noted that the above analysis completely ignores the fact that trade barriers faced by developing countries include policies imposed by other developing countries. Almost 40 percent of developing country exports were imported by other developing countries in 1998, and increasingly this trade comprises manufactured products (Hertel and Martin 2000). The analysis also ignores the effect of own liberalization, which can be expected to be a major precondition for benefiting from duty-free access in the Quad.

\section{Vi. Concluding Remarks}

Although average tariffs confronting LDCs in Quad markets are very low, tariff peaks have a disproportional effect on LDC exports. Goods that are subject to MFN tariffs of 15 percent or more account for 11 percent of LDC exports to the Quad, although these types of products represent only 4 percent of total Quad imports ( $\$ 93$ billion). Of this small amount, LDCs account for less than 4 percent of total Quad imports of tariff peak items-they are very small players.

Products that are subject to tariff peaks, especially in Canada and the United States, tend to benefit from only limited preferential access. The impact of tariff peaks is therefore disproportionately greater for LDCs. Tariff peak products tend to be heavily concentrated in agriculture (sugar, cereals, and meat) and in laborintensive sectors, such as apparel and footwear.

The impact on LDC exports of tariff peak items following the Everything But Arms initiative is likely to be quite small given that preferences were already generous. The estimated increase in exports of tariff peak products is around \$185 million, less than 1 percent of total LDC exports. Excluding sugar, rice, and bananas from the analysis, duty-free access in the European Union is worth only a modest $\$ 60$ million increase in exports. However, if all Quad members were to grant duty-free access for tariff peak items, this would have a significant effect on LDC exports. The increase could be as large as an extra \$2.5 billion of LDC exports, which represents an increase of 11 percent in their total exports to the world. This would constitute a major improvement in terms of export performance.

The impact of elimination of peaks for LDCs on domestic producers in the Quad would be very small. Total import demand in the Quad would increase by a negligible $\$ 117$ million. Most of the increase in LDC exports would be explained by either displacement of exports from other sources, or tariff revenue transfers from Quad members as they grant preferential access to LDCs. There would be trade diversion: other developing countries would see their exports fall by as much as $\$ 1.135$ billion. Although this would represent 45 percent of the total increase in LDC exports, it would be negligible in terms of other developing countries' 
global exports-around 0.05 percent. Moreover, developing countries as a group (including LDCs) would see their exports increase by over $\$ 1.3$ billion, as LDC exports would expand more than other developing countries' trade contracts. The rest of the increase in LDC exports would be explained by displacement of exports from industrial countries or a decline in Quad tariff revenue.

The distribution of export increases across products and countries reflects differences in both the export bundle of LDCs and the tariff peaks in Quad countries. In terms of specific product categories and countries, the impact of abolishing tariff peaks for LDCs would be relatively concentrated. In the United States and Canada, most of the action would be in apparel. In the European Union and Japan, the action would be primarily in sugar and related products and cereals. In absolute terms, Bangladesh would be the big beneficiary, being the largest LDC exporter of apparel, footwear, and fish to the European Union, the United States, and Canada. Cambodia, Cape Verde, Haiti, Laos, Liberia, Malawi, Maldives, and Somalia would also benefit significantly, seeing their exports increase by 20 percent or more. Given that tariff peaks across Quad countries occur in different products and that LDC export bundles are quite diverse, if all Quad members were to eliminate tariff peaks, it would help ensure that a larger number of LDCs would benefit.

It is well known that protectionist trade regimes in industrial countries are not the most important factors constraining LDC export growth. Of greater importance are domestic distortions and institutional weaknesses that create high transactions costs and bias investment incentives $(\mathrm{Ng}$ and Yeats 1997; World Bank 2001). Elimination of tariff peaks would not solve the problem of the marginalization of LDCs in global trade. However, the Quad could offer to eliminate tariff peaks and thereby help offset (to some extent) the major domestic challenges and transactions costs that confront domestic entrepreneurs in LDCs. In the process, by mobilizing export-oriented groups that would benefit from improved access to the Quad, this action might help alter the domestic political economy forces that constrain the adoption and implementation of better policies.

In principle, nondiscriminatory liberalization is superior to granting preferential access in welfare terms. However, such an approach toward dealing with tariff peaks would not enhance the exports of LDCs. Any effort to reduce tariff peaks on a nondiscriminatory basis-which is the preferred option from a global efficiency perspective-should be complemented by efforts targeted at assisting poor countries to improve their capacity to use trade as part of a propoor growth strategy. Expansion of "aid for trade" should also be an element of preferential access schemes. It is generally recognized that market access without the ability to produce profitably for export is of limited value. There is a large complementary agenda that must be pursued to enhance the ability of many low-income countries to participate in the global economy. ${ }^{28}$

28. See Hoekman (2001) and World Bank (2001) for more detailed discussions and proposals. 


\section{Appendix: Data Sources}

All trade data are from the U.N. Comtrade Database (value and unit prices). MFN tariff schedules for Quad members are from the OECD compendium of tariffs, 2000. Tariff preferences have been calculated using Quad members' tariff schedules reported in the WTO-ID B database and preference data provided by the wто's Trade Policy Review division (when data were available at the eightor ten-digit level, simple averages were taken). In instances where specific tariffs are applied, we used ad valorem equivalents calculated by the OECD and the WTO Trade Policy Review division. Elasticities of import demand are assumed to be equal across countries and are constructed using data reported in Shiells, Stern, and Deardorff (1986) and Stern, Francis, and Schumacher (1976). (An Excel file is available from the authors.) Export supply elasticities are also assumed constant across countries, and, due to the lack of information at this level of disaggregation, we set its value to 0.5 (alternatively, we provide estimates with the elasticity of export supply set equal to 0 in Hoekman et al. [2001]).

\section{REFERENCES}

Bovard, James. 1991. The Fair Trade Fraud: How Congress Pillages the Consumer and Decimates American Competitiveness. New York: St. Martin's Press.

Hallaert, Jean-Jacques. 2000. "Un bilan à mi-parcours du SPG Europeen: impact du volet industriel sur les pays en developpement d'Asie.” Mimeo. Science Po (GEM), Paris.

Herin, Jan. 1986. "Rules of Origin and Differences between Tariff Levels in EFTA and in the Ec." Aele Occasional paper no. 13, Geneva.

Hertel, Thomas, and Will Martin. 2000. "Liberalizing Agriculture and Manufactures in a Millennium Round.” World Economy 23(4):455-70.

Hoekman, Bernard. 2001. "Strengthening the Global Trade Architecture for Development.” DECRG, World Bank, mimeo.

Hoekman, Bernard, and Michel Kostecki. 2001. The Political Economy of the World Trading System. Oxford: Oxford University Press.

Hoekman, Bernard, Francis Ng and Marcelo Olarreaga. 2001. "Eliminating Excessive Tariffs in the Quad and Least Developed Country Exports." Policy Research Working Paper No. 2604, World Bank, Washington, D.C. Available online at www.worldbank.org/trade.

Ianchovichina, Elena, Aaditya Mattoo, and Marcelo Olarreaga. 2001. "Unrestricted Market Access for Sub-Saharan Africa: How Much Is It Worth and Who Pays for It?” Policy Research Working Paper No. 2595, World Bank, Washington, D.C. Available online at www.worldbank.org/trade.

Kennan, Jane, and Christopher Stevens. 1997. "From Lomé to the GSP: Implications for the ACP of Losing Lomé Trade preferences." Institute of Development Studies, University of Sussex.

Michalopoulos, Constantine. 1999. "Trade Policy and Market Access Issues for Developing Countries: implications for the Millennium Round.” Policy Research Working Paper No. 2214, World Bank, Washington, D.C. 
Ng, Francis, and Sandy Yeats. 1997. "Open Economies Work Better! Did Africa's Protectionist Policies Cause its Marginalization in World Trade?" World Development 25(6):889-904.

OECD. 1997. Indicators of Tariff and Non-Tariff Barrier. OECD, Paris.

- 2000. Tariffs and Trade: OECD Query and Reporting System. CD-ROM, OECD, Paris.

Sapir, André. 1997. "The Political Economy of Ec Regionalism.” European Economic Review 42:717-32.

Shiells, Christina, Robert Stern, and A. Deardorff. 1986. "Estimates of the Elasticities of Substitutions between Imports and Home Goods for the United States." Weltwirtschaftliches Archiv 122:497-519.

Stern, Robert, J. Francis, and B. Schumacher. 1976. Price Elasticities in International Trade: An Annotated Bibliography. London: Macmillan.

Stevens, Christopher, and Jane Kennan. 2000. "Analysis of EU Trade Arrangements with Developing and Transition Economies.” Institute of Development Studies, University of Sussex.

UnCTAD. 2001. Duty and Quota Free Market Access for LDCs: An Analysis of QUAD Initiatives. UNCTAD, Geneva.

World Bank. 2001. Global Economic Prospects and the Developing Economies. Washington, D.C: World Bank. 